\title{
Økonomisk vakst, produktion og divergens i transitionslandene
}

\author{
Karsten Stæhr* \\ Tallinns Tekniske Universitet og Eesti Pank, Estland
}

\begin{abstract}
Economic growth, production and divergence in the transition countries This article examines developments in income and living standards in the post-communist transition countries. All of these countries had planned economies but differed greatly in their economic and institutional starting points at the time of transition. The extent and speed of reforms has also varied. Production has increased considerably, but many of these transition countries have experienced severe business-cycle fluctuations. Although they have generally narrowed the income gap between them and the world's richest nations, there are clear signs of divergence, with some of the poorest transition countries making very slow progress here. This is especially the case with the countries of the former Soviet Union and, to a lesser extent, the Balkan countries, but not the 11 countries that have joined the EU. Thus, the economic gains of the post-communist transition have been very uneven across countries.
\end{abstract}

Keywords: transition countries, economic growth, income convergence, income divergence

\section{Indledning}

Den post-kommunistiske transitionsproces begyndte omkring 1990 da Polen og Ungarn som de første lande begyndte den omfattende reformproces. Efter næsten 30 år har støvet lagt sig og det er muligt at danne sig et overblik over de økonomiske resultater, hvoraf udviklingen i produktion og indkomster er af størst betydning. Hovedspørgsmålet er i hvilket omfang transitionslandene har indsnævret indkomstgabet til de udviklede lande iVesteuropa og Nordamerika, herunder hvordan forskellige lande og landegrupper har klaret sig.

Denne artikel fokuserer på transitionslandene, den gruppe af tidligere kommunistiske lande som gennemførte omfattende politiske og økonomiske reformer i begyndelsen af 1990'erne. Det er i første række de lande som blev etableret efter sammenbruddet af Jugoslavien og Sovjetunionen, men også mange lande i

\footnotetext{
^Kontaktinformasjon: Karsten Stæhr, epost: karsten.staehr@ttu.ee 
Central- og Østeuropa og endelig Mongoliet. Efter Kosovos selvstændighed i 2008 talte denne gruppe i alt 30 lande. ${ }^{1}$

Gorbatjovs reformer førte til et tab af Sovjetunionens hegemoni og frisatte en række centrifugale kræfter i såvel Sovjetunionen som resten af østblokken. Krav om frihed, national selvbestemmelse og økonomiske reformer kom op til overfladen. Polen afholdt delvist demokratiske valg i 1989, landene i Central- og Østeuropa fulgte året efter, mens 15 nye lande opstod eller genopstod efter sammenbruddet af Sovjetunionen i 1991.

Det politiske opbrud muliggjorde økonomiske reformer som i de fleste af landene betød afskaffelse af statsligt ejerskab, planlægning og faste priser. De økonomiske reformer var på sin vis et biprodukt af den politiske forandringsproces, men de kan også ses som en integreret del af reformprocessen givet at ønsket om mere frihed og flere valgmuligheder også vedrørte det økonomiske område. Introduktionen af markedsøkonomi blev set som et middel til at skabe økonomisk vækst og dermed en reduktion af det betydelige indkomstgab som de kommunistiske lande havde over for markedsøkonomierne i Vesteuropa og Nordamerika (Blanchard, Dornbusch, Krugman, Layard \& Summers, 1991).

Udviklingen i transitionslandenes produktion har været genstand for talrige akademiske og politikorienterede studier, til dels motiveret af ønsket om at reformerne ville bidrage til en hurtig indsnævring af indkomstgabet i forhold til Vesten. Der har været succeser, men også skuffelser (Kornai, 2006).

Mange studier fokuserer på de store produktionsfald som landene oplevede i begyndelsen af 1990'erne og forsøger at finde årsager hertil (Iwasaki \& Kumo, 2016). Andre belyser den spirende vækst i 1990'erne, herunder betydningen af landenes økonomiske og strukturelle udgangspunkter og de gennemførte reformer (De Melo, Denizer, Gelb \& Tenev, 2001; Staehr, 2005; Falcetti, Lysenko \& Sanfey, 2006). Endelig er der studier af produktionsudviklingen under og efter den globale finanskrise. Den relativt lave vækst efter krisen har givet anledning til bekymring for landenes fremtidige økonomiske udvikling, herunder risikoen for at landene bliver fanget $\mathrm{i}$ en mellemindkomstfælde hvor indkomstgabet i forhold til Vesten indsnævres meget langsomt (Staehr, 2015; EBRD, 2017).

Denne artikel giver en oversigt over udviklingen i vækst og produktion i transitionslandene siden begyndelsen af 1990'erne og bidrager til den litteratur som tester for konvergens, altså hvorvidt indkomstgabet over for de udviklede økonomier indsnævres. Studier som Estrin, Urga og Lazarova (2001), Rapacki og Prochniak (2009) og Varblane og Vahter (2006) præsenterer også statistiske analyser af konvergensprocessen, men anvender i modsætning til nærværende artikel udelukkende

\footnotetext{
${ }^{1}$ Udviklingen $\mathrm{i}$ andre lande som har eller har haft kommunistisk styre bliver kun diskuteret sporadisk. Kina begyndte sine økonomiske reformer i 1978, men kommunistpartiet er fortsat eneste tilladte parti. Andre lande som - $\mathrm{i}$ hvert fald af navn - har beholdt et kommunistisk styre inkluderer Laos, Cambodia, Vietnam, Nordkorea, Cuba og enkelte lande i Latinamerika og Afrika.
} 
data fra perioden før den globale finanskrise og inddrager generelt ikke alle 30 transitionslande. Resultaterne fra tidligere studier varierer markant afhængigt af hvilket udvalg af lande og år som indgår i analysen.

Artiklen maler med en bred pensel og analyserer generelt ikke udviklingen i enkeltlande. Fokus ligger på udviklingen i bruttonationalproduktet BNP, den samlede værditilvækst $\mathrm{i}$ en økonomi. BNP er af stor betydning for den levestandard som det er muligt at opnå i et samfund. Der er givetvis mange andre faktorer, som har betydning for økonomisk velfærd. FN's Human Development Index inddrager således forventet levetid og læsefærdigheder sammen med BNP per capita. De fleste alternative velfærdsmål er imidlertid tæt korrelerede med BNP per capita. Samtidig kan sammenvejning af forskellige velfærdsmål give misvisende resultater givet at vægtningen grundlæggende er arbitrær og kan afspejle normative præferencer (Mcgillivray, 1991).

Denne artikel består af yderligere fem afsnit. Afsnit 2 drøfter transitionslandenes økonomiske og institutionelle udgangspunkter. Afsnit 3 præsenterer data for den økonomiske vækst i transitionsfasen og senere. Afsnit 4 fokuserer på produktionsudviklingen siden 1995. Afsnit 5 indeholder analyser af forskellige former for økonomisk konvergens i landene. Afsnit 6 afrunder.

\section{Udgangspunkt og økonomiske reformer}

De kommunistiske lande havde alle de jure eller de facto etpartisystemer og magtudøvelsen var totalitaristisk eller autoritær. Landene havde planøkonomier hvor statslige virksomheder dominerede, og produktion og priser blev fastlagt fra centralt hold. Privat ejendomsret var typisk begrænset til ejerskab af egen bolig, sommerhus, bil og eventuel opsparing. Nogle lande, herunder Ungarn og Jugoslavien, havde dog systemer hvor dele af produktionen var bestemt af udbud og efterspørgsel.

Polen introducerede fra januar 1990 omfattende markedsøkonomiske reformer. Andre lande i Central- og Østeuropa og på Balkan begyndte omstillingen til markedsøkonomi fra begyndelsen 1991, mens de 15 nye lande, som opstod i forbindelse med sammenbruddet af Sovjetunionen, fulgte efter fra august 1991. I løbet af få år blev der således gennemført reformer som omkalfatrede de politiske og økonomiske systemer i den store gruppe af lande som i eftertiden er blevet betegnet som transitionslandene.

De økonomiske og institutionelle udgangspunkter for den økonomiske reformproces var langt fra ens i transitionslandene. Lande som Tjekkiet, Slovenien og Ungarn var økonomisk bedre stillet end mange andre lande i gruppen. Polen og Ungarn og de fleste lande som udgik fra Jugoslavien havde en vis erfaring med markedsøkonomisk styring, mens dette typisk ikke var tilfældet i de lande som udgik fra Sovjetunionen.

For at kvantificere forskellene mellem de postkommunistiske landes utgangspunkter sammenvejer De Melo et al. (2001) en række økonomiske og strukturelle 


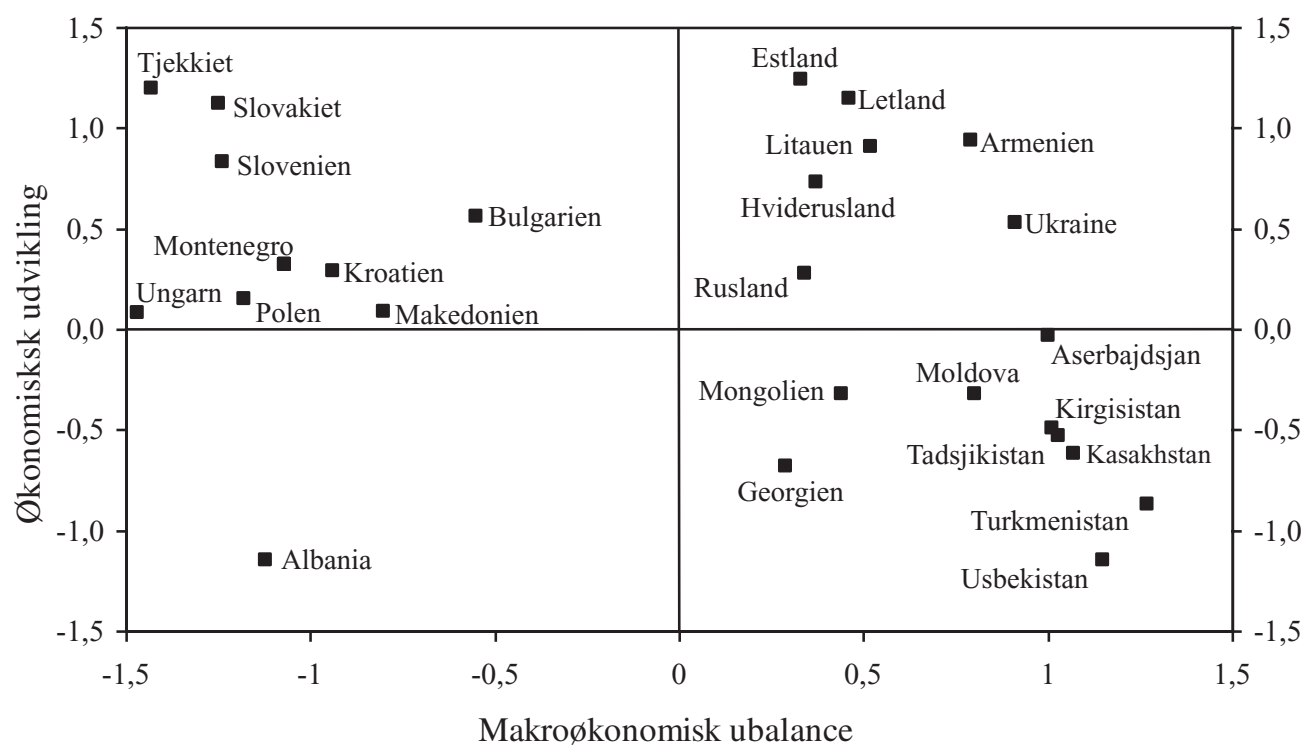

Figur 1. Transitionslandenes økonomiske og strukturelle utgangspunkt. Kilde: De Melo et al. (2001).

indikatorer for 1990 eller tidligere år og danner dermed to hovedkomponenter, som afspejler graden af henholdsvis makroøkonomisk ubalance og økonomisk udvikling. ${ }^{2}$ Figur 1 viser de to komponenter for hovedparten af transitionslandene.

Figur 1 illustrerer tydeligt at transitionslandenes økonomiske og institutionelle udgangspunkter var meget forskellige. Landene fra Sovjetunionen havde omkring 1990 generelt omfattende makroøkonomiske og institutionelle ubalancer, og samtidig varierede udviklingsniveaet betydeligt således at landene mod vest var mere udviklede end de centralasiatiske lande længere mod øst. Landene i Central- og Østeuropa havde generelt færre ubalancer end landene fra den tidligere Sovjetunion og samtidig et relativt højt udviklingsniveau. I dette lys synes udgangspunktet at have været bedre for de central- og østeuropæiske lande end for landene længere $\bmod ø s t$.

Den grundlæggende idé bag de økonomiske reformer var hurtigt at indføre markedsøkonomier, hvilket i praksis blev udmøntet gennem en kombination af fire overordnede reformelementer (Blanchard et al., 1991): Liberalisering af produktion,

\footnotetext{
${ }^{2}$ De Melo et al. (2001) bruger data for BNP per capita, graden af urbanisering, industriens størrelse, et indeks for "overindustrialisering", geografisk placering, ressourcerigdom, økonomisk vækst før transitionen, undertrykt inflationspres, afhængighed af handel, forskellen mellem valutakursen officielt og på sortbørsen, institutionel erfaring samt antal år under centralplanlægning. Vægtede indekser er derefter konstrueret ved brug af principal components, hvor den første hovedkomponent fortolkes som et mål for makroøkonomiske ubalancer og den anden hovedkomponent som et mål for det økonomiske udviklingsniveau. En høj grad af makroøkonomisk ubalance sammenfalder typisk med overindustrialisering, koncentreret handel, undertrykt inflation og lignende.
} 
handel og prisdannelse. Privatisering af alle små virksomheder og de fleste store virksomheder. Stabilisering af inflation, statsfinanser og banker. Strukturreformer inden for områder som ejendomsret, konkurslovning, offentlig administration, retsvæsen, social sikring osv.

Omfanget, timingen og rækkefølgen af reformerne varierede betydeligt mellem landene. Der opstod i 1990'erne livlige akademiske debatter om det optimale reformtempo, sammensætning og rækkefølge af de forskellige reformelementer (Roland, 1994). Det er vanskeligt at vurdere om den akademiske debat i praksis satte sig spor i reformprocessen. Generelt var de central- og østeuropæiske lande de hurtigste til at gennemføre de markedsøkonomiske reformer, dernæst fulgte de krigshærgede lande på Balkan og til sidst de fleste af landene fra den tidligere Sovjetunion (Staehr, 2006). Der er dog stor variation inden for disse grupper, og for eksempel har reformintensiteten været langt større i Estland end i Hviderusland eller Turkmenistan.

I praksis viste det sig at omfanget af økonomiske reformer i høj grad fulgte omfanget af politiske reformer (Fidrmuc, 2003). Transitionslande som indførte demokrati gennemførte således flere økonomiske reformer end landene med autokratisk styre. Staehr (2006) finder at årsagssammenhængen går fra politiske reformer til økonomiske reformer, mens der ikke er nogen sammenhæng i den modsatte retning. ${ }^{3}$ Demokratisering synes altså at være en vigtig faktor bag reformprocessen.

\section{Transition og vækst}

De økonomiske reformer i transitionsfasen frem til år 2000 ændrede fundamentalt på økonomiernes incitamentsstrukturer og funktionsmåde. Processen var på mange områder vanskeligere og resultaterne mere ujævne end forventet. Den største overraskelse var de store produktionsfald som de fleste af landene oplevede i begyndelsen af perioden.

Data over produktion og dermed vækst for den tidlige transitionsperiode er forbundet med stor usikkerhed og mangler helt for de fleste af landene. Transitionen var for mange lande stort set tilendebragt fra omkring 2000 og data er herefter noget mere pålidelige. Det er imidlertid vigtigt at understrege at der for de fleste af landene har været talrige revisioner af data på grund af omlægninger af statistiksystemer og tilpasninger af datadefinitioner og opgørelsesmåder. Dette betyder desværre også at data fra forskellige kilder ofte afviger noget.

På grund af manglende data er det ikke muligt at gengive vækstdynamikken for alle transitionslandene. Data fra 1990 er imidlertid tilgængelige for visse af landene. Figur 2 viser væksten i den samlede produktion, realt BNP, i Polen, Estland, Rusland

\footnotetext{
${ }^{3}$ En mulig forklaring er at eliterne i autokratiske lande ikke ønsker velfungerende markedsøkonomier da delvist reformerede og oligarkiske økonomier giver eliterne de bedste muligheder for rent seeking (Hellman, 1998).
} 


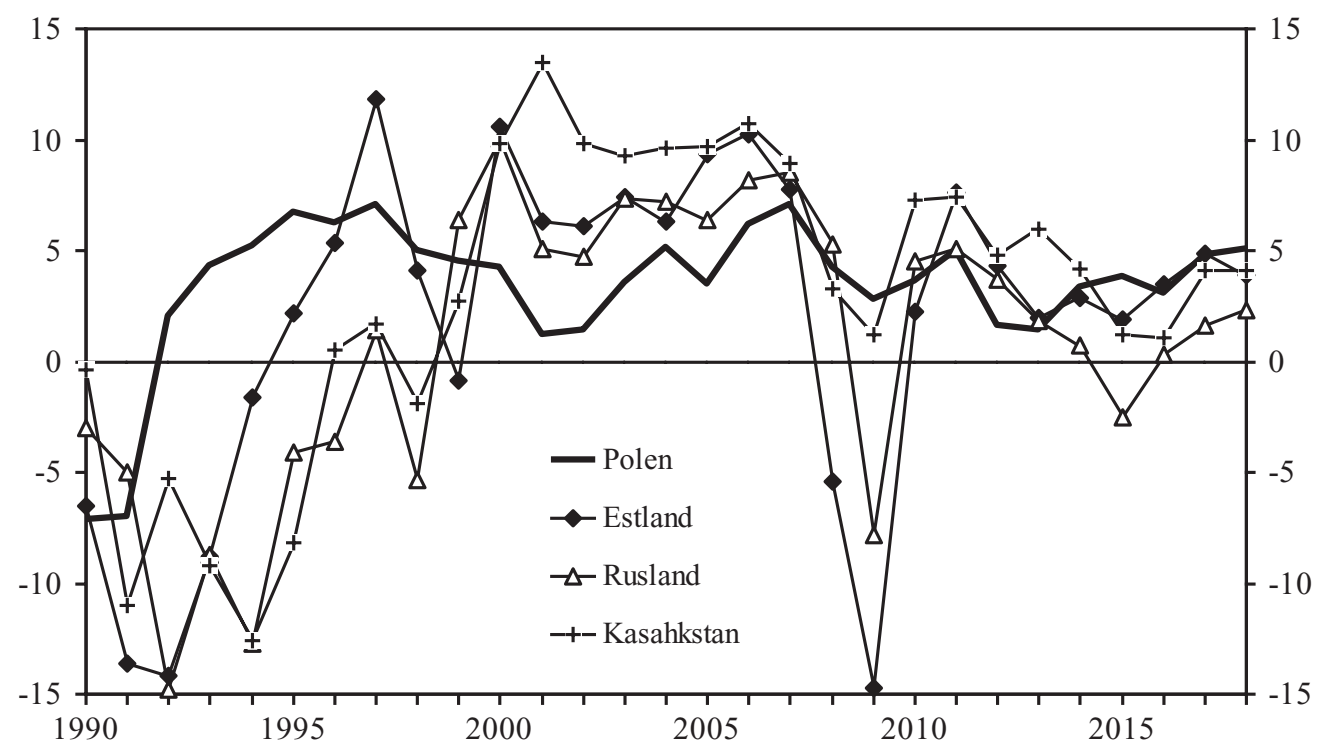

Figur 2. Realt BNP, procent vækst per år. Kilder: WEO (2019) og EBRD (2010).

og Kasakhstan. Udviklingen i de fire lande illustrerer udviklingstræk som gælder for mange af de øvrige transitionslande.

Polen begyndte som nævnt landets omfattende reformer allerede i 1990 og produktionen faldt med over 7 procent det første år og yderligere 7 procent det følgende år. Produktionsfald af en sådan størrelse er sjældne i historisk sammenhæng, og i Europa skal man tilbage til 2. verdenskrig for at se tilsvarende produktionsfald. Situationen i Polen bedredes imidlertid relativt hurtigt. Den økonomiske vækst var således positiv allerede i 1992, og det har faktisk været situationen helt frem til og med 2018. Polen adskiller sig fra de øvrige transitionslande ved at landet kun har haft moderate konjunkturudsving siden begyndelsen af 1990'erne.

Estland havde negativ BNP-vækst i 1990-1991. Landets økonomi skrumpede således allerede inden landet igen blev selvstændigt og før reformerne for alvor begyndte. Fra midten af 1990'erne har Estlands vækst været høj, men meget svingende. Ruslands krise i 1998 fik alvorlige følger i Estland året efter, men det største tilbageslag kom i kølvandet på den globale finanskrise i 2008.

Rusland og Kasakhstan oplevede i lighed med andre transitionslande store produktionsfald i begyndelsen af 1990'erne. Det er imidlertid bemærkelsesværdigt, at mens lande som Polen og Estland relativt hurtigt opnåede positive vækstrater, skete dette for Rusland og Kasakhstans vedkommende først i anden halvdel af 1990'erne. Rusland har efterfølgende oplevet kraftige konjunkturudsving, mens Kasakhstan, omend vækstraterne har været faldende over tid, har haft en mere stabil udvikling.

Den økonomiske udvikling i transitionslandene afspejler mange faktorer. Det første årti var en periode med omfattende reformer, men fra omkring år 2000 var 
processen stort set afsluttet og de økonomiske strukturer og institutioner har siden været relativt stabile i de fleste transitionslande. ${ }^{4}$ Det betyder også at den økonomiske udvikling siden år 2000 nok relaterer sig til transitionsprocessen, men også til mange andre faktorer (Coricelli \& Campos, 2002).

De store produktionsfald i begyndelsen af transitionsprocessen og den efterfølgende fremgang gav anledning til en omfattende akademisk litteratur som søgte at analysere i hvilket omfang de post-kommunistiske markedsreformer kunne forklare udviklingen. Babecký og Campos (2011) sammenfattede resultaterne fra et stort antal studier i en meta-analyse og konkluderede at det ikke er muligt at fastslå en entydig forbindelse mellem omfanget af reformer og økonomisk vækst i transitionsfasen. Dette resultat er måske ikke overraskende givet de usikre data og det faktum at den empiriske litteratur finder relativt få faktorer som, på pålidelig vis, kan forklare økonomisk vækst (Barro \& Sala-i-Martin, 2004; Jones, 2016).

De store produktionsfald i begyndelsen af 1990'erne og den følgende svage udvikling i Rusland og andre lande førte til en kritik af de økonomiske reformer og deres markedsorientering. Stiglitz (2000) sammenlignede produktionsudviklingen i Rusland og Kina i 1990'erne og konkluderede at kinesernes langsommere reformtempo havde givet de bedste resultater. Dette blev imødegået af blandt andet Dabrowski, Gomulka og Rostowski (2001) som argumenterede for at Ruslands reformer faktisk havde været langsomme og ufuldstændige, og at landet havde haft et svagt udgangspunkt som følge af Sovjetunionens sammenbrud. Fortsat florerer variationer af denne debat, herunder specielt om statens rolle i udvikling af økonomien og mulighederne for at føre industripolitik som fremmer sektorer med betydeligt vækstpotentiale (Berglof et al., 2015).

Perioden fra slutningen af 1990'erne til 2008 var en gylden periode. Den årlige økonomiske vækst lå på mellem 5 og 10 procent i mange af transitionslandene og ofte med en stigende tendens. I nogle lande, herunder Rusland og Kasakhstan, var boomet til dels drevet af stigende priser på olie, gas og andre råvarer. I flere lande i Central- og Østeuropa og på Balkan førte stor kapitalindstrømning til et forbrugs- og investeringsboom med overophedning af økonomierne til følge (Staehr, 2018).

Med udbruddet af den globale finanskrise i 2008 vendte kapitalstrømmene, eksporten faldt og tilliden blandt forbrugere og virksomheder dalede dramatisk. Konsekvensen var store produktionsfald i mange transitionslande, særligt i 2009. Krisen ramte landene forskelligt, men blandt landene i Central- og Østeuropa og på Balkan er det kun Polen som ikke havde nogen produktionsnedgang i 2009. Faldet i BNP i Estland var af en størrelsesorden som er sammenlignelig med faldet i den tidlige transitionsfase. Flere lande, herunder Ungarn, Letland og Rumænien, fik så store finansielle problemer at de måtte indgå låneaftaler med blandt andet Den Internationale Valutafond, IMF.

\footnotetext{
${ }^{4}$ Det fremgår for eksempel af de økonomiske reformindekser som publiceres af EBRD, den Europæiske Bank for Genopbygning og Udvikling; se for eksempel EBRD (2010).
} 
Efter at de umiddelbare dønninger fra finanskrisen har lagt sig, har væksten i transitionslandene været relativt stabil, men også forholdsvis lav over en længere periode. ${ }^{5}$ Denne situation, hvor en finanskrise bliver fulgt af en langvarig vækstnedgang, er også kendt fra flere lande i Latinamerika og Asien. Disse lande har gennem årtier været ude af stand til at indsnævre indkomstgabet over for de udviklede lande i betydelig grad. Den svage vækst i 2010'erne har givet anledning til bekymring for om flere af transitionslandene er eller er ved at blive fanget i en mellemindkomstfelde, hvor den underliggende vækst er så lav at landene ikke indsnævrer indkomstgabet over for de udviklede lande (Staehr, 2015; EBRD, 2017). En sådan fælde med svag økonomisk udvikling over længere tid kunne for eksempel skyldes forhold ved et lands uddannelsessystem, infrastruktur, emigration eller politiske system.

Som det fremgår af figur 2 er væksten i mange transitionslande i 2017 og 2018 højere end de foregående år, og det har reduceret de umiddelbare bekymringer for landenes vækstbillede. Krisen og den efterfølgende produktionsnedgang har imidlertid gjort det klart at mange af disse lande fortsat er udsat for kraftige konjunkturudsving og står overfor store udfordringer hvis de skal lykkes med at indsnævre indkomstgabet over for de udviklede lande i Vesteuropa og Nordamerika.

\section{Produktion og købekraft}

Forrige afsnit drøftede væksten i den reale produktion, altså udviklingen i produktionen målt i faste priser. Dette er nyttigt for at vurdere udviklingen over tid inden for et land, men er ikke nødvendigvis formålstjenligt, hvis man vil sammenligne den økonomiske situation på tværs af landegrænser. Til det formål er det bedre at bruge den købekraftkorrigerede værdi af produktionen per indbygger, dvs. BNP per capita PPP (purchasing power parity).

BNP per capita PPP betegner produktionen per indbygger korrigeret for forskelle i prisniveauerne i de lande som sammenlignes. ${ }^{6}$ Det afspejler med andre ord købekraften af den samlede produktion når der købes produkter som indgår $\mathrm{i}$ det relevante indenlandske prisindeks. Det kan med lidt god vilje fortolkes som et grovmasket mål for den gennemsnitlige levestandard i et land. Andre faktorer såsom omfanget af investeringer, kapitalstrømme til og fra udlandet samt indkomster fra den uformelle økonomi, som ikke afspejles i BNP-data, er naturligvis også af betydning for levestandarden på et givet tidspunkt.

\footnotetext{
${ }^{5}$ Levenko, Oja og Staehr (2019) belyser udviklingen i de transitionslande som er medlemmer af EU og finder at mens totalfaktorproduktiviteten, dvs. effektiviteten hvormed økonomiens ressourcer udnyttes, voksede betydeligt før krisen, faldt den markant under krisen og stod herefter i stampe i perioden 2011-2016.

${ }^{6}$ Mange transitionslande har oplevet store fald i befolkningstallet på grund af emigration, lave fødselsrater og overdødelighed blandt især mænd. Det er derfor rimeligt at betragte produktionen per indbygger, dvs. BNP per capita. Endvidere er prisniveauet meget forskelligt i landene, bl.a. fordi serviceydelser som taxikørsel, hårklipning og reparationer typisk ikke handles internationalt.
} 
For at sammenligne indkomstniveauet $\mathrm{i}$ forskellige lande er det praksis at udtrykke et lands BNP per capita PPP i forhold til det samme mål i et udviklet referenceland. Som i mange andre studier af indkomstforskelle i transitionslandene er USA valgt som referenceland. Dette skyldes at USA har det højeste indkomstniveau blandt verdens større lande og dermed det højeste indkomstniveau som transitionslandene kan tilstræbe at nå. USA er også et godt referenceland da landet - i modsætning til flere lande i Vesteuropa - ikke var direkte påvirket af transitionsprocessen.

Tabel 1. BNP per capita PPP, procent af USA's

\begin{tabular}{|c|c|c|c|c|}
\hline & 1995 & 2000 & 2008 & 2018 \\
\hline \multicolumn{5}{|l|}{ CEE11 } \\
\hline Bulgarien & 23,8 & 20,6 & 32,1 & 37,0 \\
\hline Estland & 28,3 & 33,6 & 50,5 & 54,5 \\
\hline Kroatien & 33,4 & 34,4 & 43,2 & 41,9 \\
\hline Letland & 21,2 & 24,6 & 42,7 & 47,8 \\
\hline Litauen & 23,8 & 26,6 & 46,7 & 55,6 \\
\hline Polen & 28,5 & 32,1 & 40,1 & 51,0 \\
\hline Rumænien & 26,4 & 21,9 & 36,1 & 42,2 \\
\hline Slovakiet & 33,8 & 34,0 & 50,3 & 56,1 \\
\hline Slovenien & 46,9 & 49,7 & 62,2 & 58,7 \\
\hline Tjekkiet & 48,6 & 45,9 & 58,2 & 59,7 \\
\hline Ungarn & 39,3 & 39,5 & 47,5 & 51,0 \\
\hline \multicolumn{5}{|l|}{ Balkan6 } \\
\hline Albanien & 10,3 & 11,5 & 17,6 & 21,3 \\
\hline Bosnien & .. & 14,3 & 19,0 & 21,5 \\
\hline Kosovo &.. & 13,4 & 15,3 & 18,5 \\
\hline Nordmakedonien & 20,4 & 19,8 & 22,9 & 25,1 \\
\hline Montenegro & .. & 22,0 & 28,6 & 30,4 \\
\hline Serbien & .. & 16,9 & 26,2 & 28,0 \\
\hline \multicolumn{5}{|l|}{ xSovjet13 } \\
\hline Armenien & 5,5 & 6,3 & 14,7 & 16,3 \\
\hline Aserbajdsjan & 9,1 & 10,4 & 29,0 & 28,9 \\
\hline Georgien & 5,9 & 7,7 & 13,4 & 18,3 \\
\hline Hviderusland & 13,9 & 16,5 & 29,8 & 32,0 \\
\hline Kasakhstan & 21,3 & 21,8 & 37,6 & 44,0 \\
\hline Kirgisistan & 4,3 & 4,6 & 5,5 & 6,1 \\
\hline Moldova & 8,1 & 6,2 & 9,3 & 11,7 \\
\hline Mongoliet & 11,3 & 10,4 & 14,9 & 21,5 \\
\hline Rusland & 32,7 & 30,8 & 47,6 & 46,7 \\
\hline Tadsjikistan & 2,9 & 2,6 & 4,0 & 5,5 \\
\hline Turkmenistan & 7,3 & 7,1 & 17,6 & 31,2 \\
\hline Ukraine & 13,5 & 11,0 & 17,6 & 14,8 \\
\hline Usbekistan & 5,8 & 5,6 & 7,6 & 12,2 \\
\hline
\end{tabular}

Kilder: WEO (2019). 
Tabel 1 angiver BNP per capita PPP for de 30 transitionslande som procent af USA's for årene 1995, 2000, 2008 og 2018. For flere lande mangler data som tidligere nævnt for perioden 1995-1999. Landene er opdelt i landegrupper, i nogen grad sammensat efter geografiske kriterier. Gruppen CEE11 består af de central- og østeuropæiske lande, inklusive de tre baltiske lande, Estland, Letland og Litauen, som blev medlemmer af EU ved udvidelserne i 2004, 2007 og 2011. Gruppen Balkan6 er de lande på Balkan som i 2019 fortsat står uden for EU. Endelig udgør gruppen $x$ Sovjet13 landene fra den tidligere Sovjetunion undtaget de baltiske lande, men inklusive Mongoliet (som havde kommunistisk styre og planøkonomi, men ikke var en del af Sovjetunionen).

Landene i CEE11 er generelt de mest velstående af transitionslandene med BNP per capita PPP i 2018 på 40-60 procent af det amerikanske. Herefter følger landene i Balkan6 som har indkomst per capita på 20-30 procent af det amerikanske niveau. Landene i xSovjet13 har meget forskellige indkomstniveauer med Rusland og Kasakhstan som de rigeste og Kirgisistan og Tadsjikistan som de fattigste. ${ }^{7}$

Det kan være informativt at sammenligne transitionslandenes indkomstniveauer med niveauet i andre lande (WEO, 2019). I 2018 var BNP per capita PPP relativt til USA's 83,3 procent for Danmark, 84,6 procent for Sverige og 118,8 procent for olielandet Norge. Der er altså fortsat et betydeligt gab mellem indkomstniveauet i de mest velstående transitionslande og i de skandinaviske lande. Omvendt havde de mest velstående transitionslande i 2018 indhentet sydeuropæiske lande som Grækenland (46,5 procent) og Portugal (51,1 procent), og de er tæt på niveauet i Spanien (64,1 procent).

De fattigste transitionslande findes især i Centralasien og Kaukasus. I 2018 var indkomstniveauet $\mathrm{i}$ disse lande omkring 5-10 procent af det amerikanske. Til sammenligning er indkomstniveauet i Kenya 5,0 procent af USA's, mens Indien og Marokko når op på henholdsvis 10,6 procent og 12,0 procent. De mindst velstående transitionslande er således blandt verdens fattigste lande; de økonomiske og politiske forandringer har med andre ord ikke løftet befolkningerne i disse lande ud af fattigdom.

Figur 3 viser udviklingen i BNP per capita PPP over tid udregnet som simple gennemsnit for, henholdsvis, alle transitionslandene og de tre undergrupper CEE11, Balkan6 og xSovjet13. De forskellige vækstmønstre over tid fremgår klart hvis gruppen af alle transitionslandene betragtes. Frem til årtusindeskiftet var det gennemsnitlige indkomstniveau i landene stort set uændret $\mathrm{i}$ forhold til det

\footnotetext{
${ }^{7}$ Indkomstniveauerne i nogle af de fattigste lande i xSovjet13 forekommer at være meget lave hvilket dels afspejler meget store produktionsfald i årene umiddelbart før og efter Sovjetunionens sammenbrud og en efterfølgende svag økonomisk udvikling. Levestandarden er formentligt højere end de officielle produktionstal tilsiger. I de fleste af landene er den uformelle økonomi meget stor (Schneider, Buehn \& Montenegro, 2010). Endvidere arbejder mange gæstearbejdere fra landene i blandt andet Rusland, og de overfører typisk dele af deres indkomst til familierne i hjemlandet.
} 


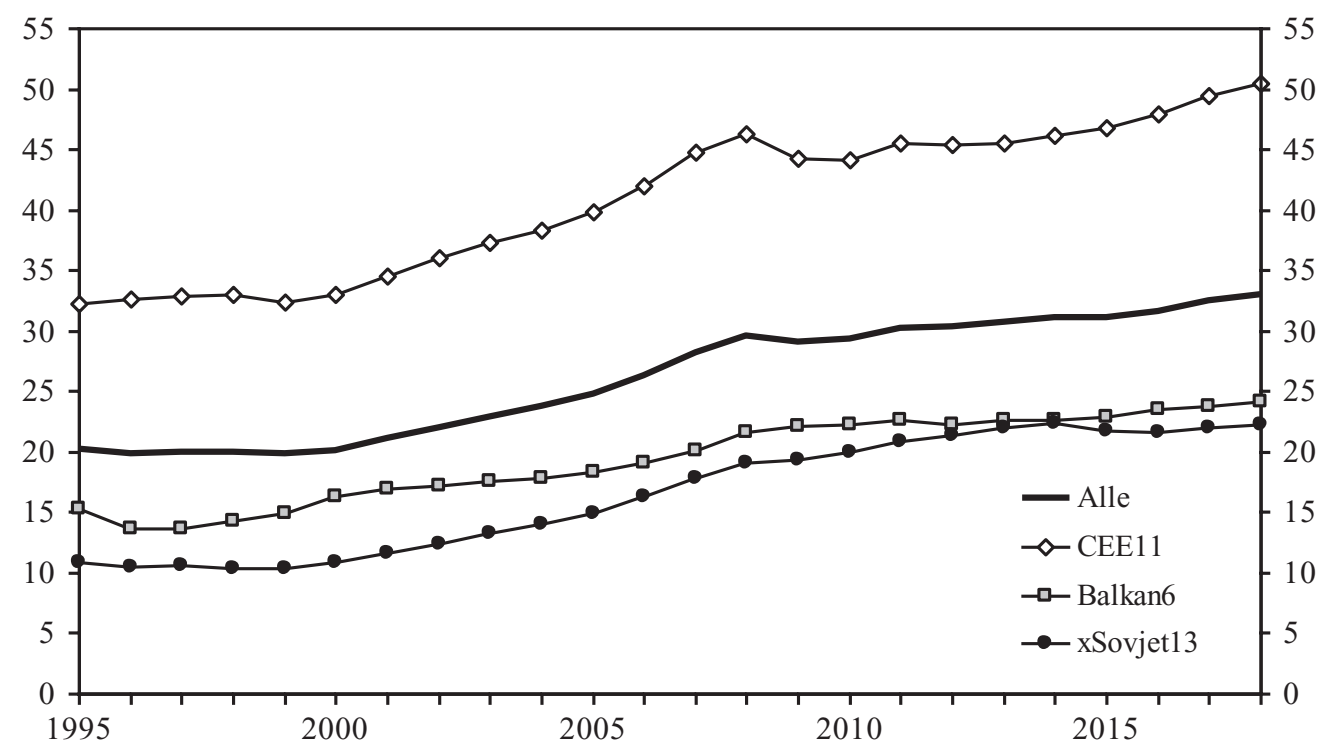

Figur 3. BNP per capita PPP 1995-2018, procent af USA's. Kilder: WEO (2019).

Note: BNP per capita PPP for de forskellige grupper af transitionslande er udregnet som simple gennemsnit af landene i grupperne. I gruppen Balkan6 mangler data for 1995 for fire lande og for 1996-1999 for tre lande.

amerikanske. Perioden fra 2000 til 2008 var en gylden periode hvor den gennemsnitlige indkomst $\mathrm{i}$ transitionslandene steg fra 20 til 30 procent af den amerikanske. Siden 2008 er denne udvikling bremset op og indsnævringen af indkomstgabet har været langsom eller ikke-eksisterende. Næste afsnit analyserer disse udviklingstræk ved brug af statistiske metoder.

\section{Konvergens og divergens}

BNP per capita PPP i transitionslandene er samlet set steget relativt til det amerikanske niveau siden 1995 og særligt i perioden 2000-2008. Spørgsmålet er imidlertid hvorvidt BNP per capita er øget mest i de fattigste af landene sådan at forskellene $\mathrm{i}$ indkomstniveauer mellem landene er blevet indsnævret over tid. Spørgsmålet om indkomstkonvergens er et af de vigtigste i debatterne om økonomisk udvikling, idet konvergens implicerer at alle lande på langt sigt vil nå tilnærmelsesvis samme indkomstniveau (Barro \& Sala-i-Martin, 2004; Abreu, de Groot \& Florax, 2005). Det er således relevant at teste for konvergens af BNP per capita for de 30 transitionslande.

En vigtig konvergensindikator er spredningen af indkomstniveauet mellem landene, ofte sammenfattet med standardafvigelsen af BNP per capita PPP. En høj standardafvigelse indikerer at indkomstniveauet varierer betydeligt mellem landene, mens en lav standardafvigelse angiver en stor grad af lighed mellem landene. 


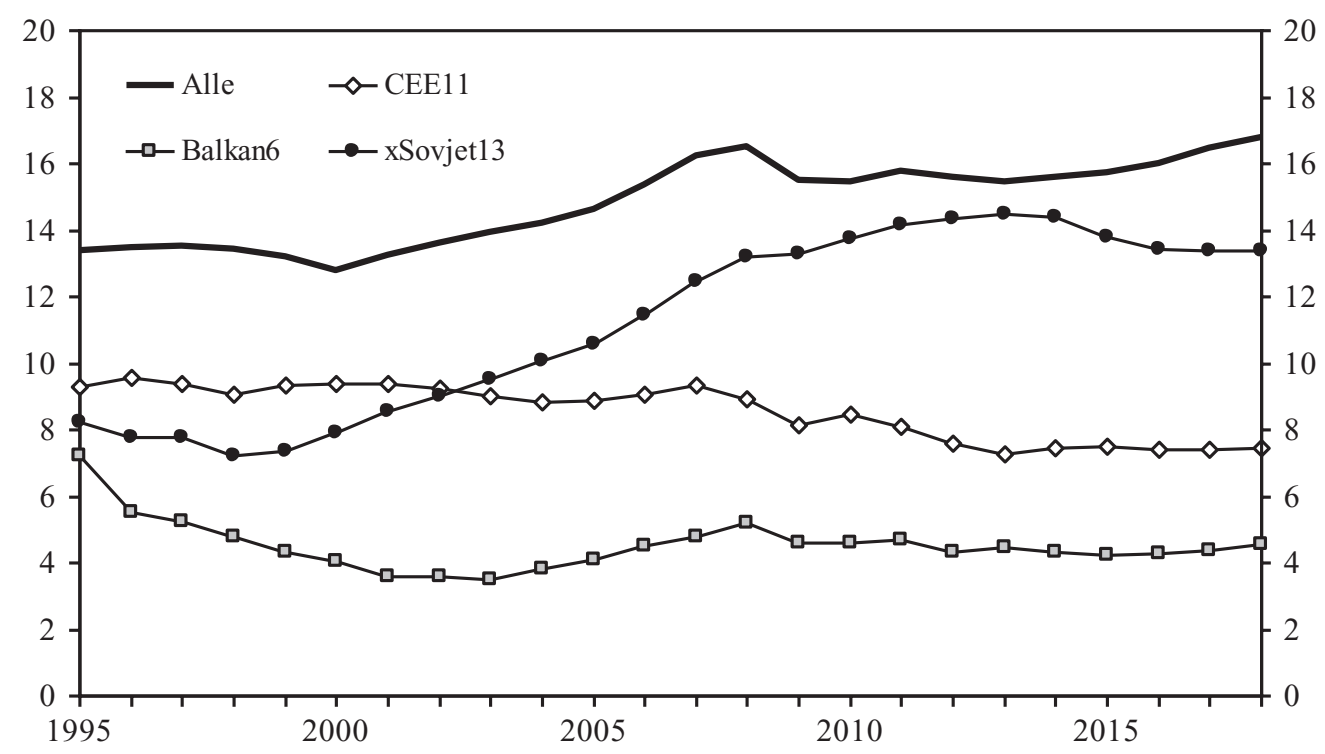

Figur 4. Standardafvigelse for BNP per capita PPP, procentpoint, 1995-2018. Kilder: WEO (2019).

Note: I gruppen Balkan6 mangler data for 1995 for fire lande og for 1996-1999 for tre lande.

Hvis standardafvigelsen falder over tid, betegnes dette som sigma-konvergens ( $\sigma$-konvergens).

Figur 4 viser standardafvigelsen for alle 30 transitionslande under et samt for hver af de tre tidligere definerede undergrupper. Standardafvigelsen er størst når alle landene inddrages. Som observeret i afsnit 4 er der betydelig ulighed mellem landene i xSovjet13, mens grupperne CEE11 og Balkan6 er mere homogene.

Dynamikken er interessant. I gruppen som består af alle landene genkendes de tre perioder som blev diskuteret i afsnit 3. Transitionen i 1990'erne betød stort set uændret ulighed mellem landene. Den stigende ulighed i 2000 'erne afspejler at selv om der var højkonjunktur i mange lande var det langt fra tilfældet i alle. Den globale finanskrise førte til større lighed i 2009 idet krisen ramte hårdest i nogle af de bedst stillede lande. Siden 2010 har standardafvigelsen dog stort set været konstant. Hvis alle transitionslandene betragtes under et og over hele perioden 1995-2018 er konklusionen derfor, at der ikke er tegn på sigma-konvergens, men derimod sigmadivergens. De 30 transitionslande er i denne betydning blevet indbyrdes mere heterogene siden kommunismens fald.

Billedet for de tre grupper viser at tendensen til sigma-divergens primært stammer fra gruppen xSovjet13. Mens lande som Rusland og Kasakhstan har indsnævret indkomstgabet til USA siden år 2000, har andre lande deriblandt Ukraine og Moldova og flere centralasiatiske lande stået i stampe. For gruppen CEE11 ses en svag tendens til sigma-konvergens. For Balkan6 mangler data for flere lande frem til 2000, men herefter synes der er ikke at være sigma-konvergens. 


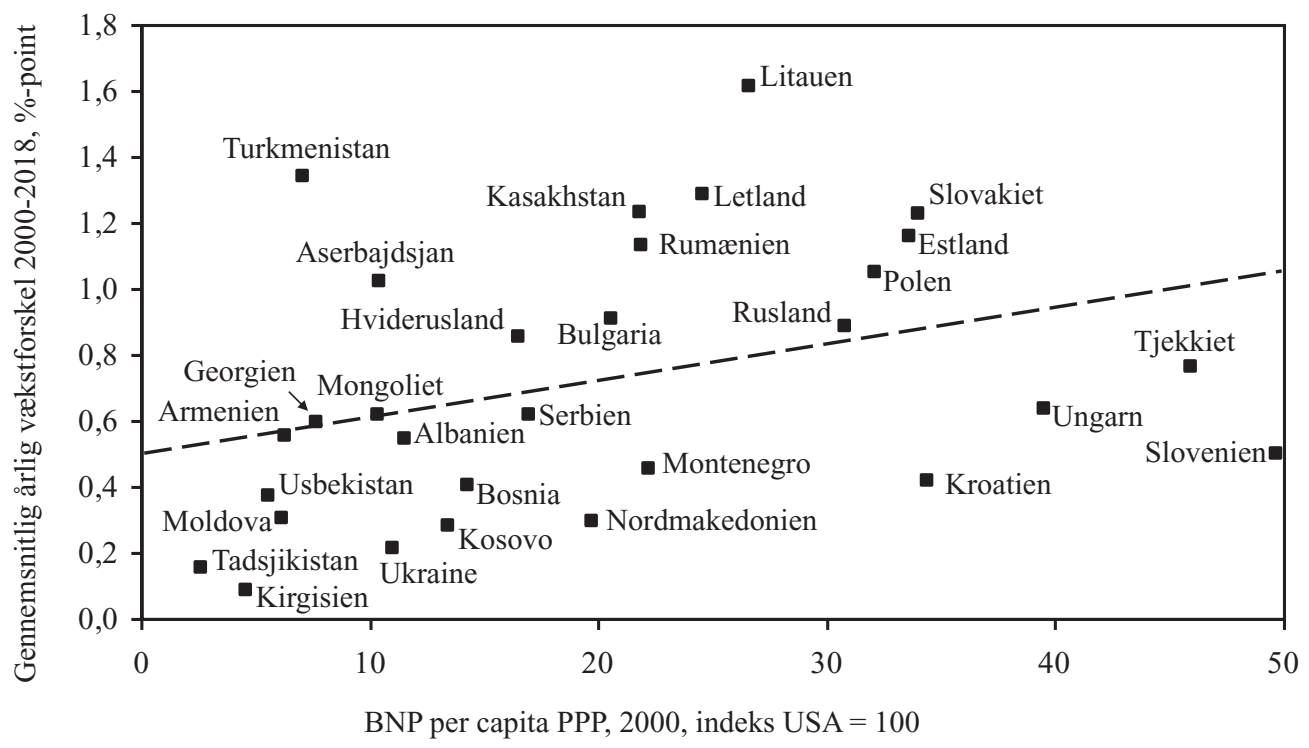

Figur 5. BNP per capita PPP i 2000 og gennemsnitlig årlig vækstforskel 2000-2018.

Note: Førsteaksen viser BNP per capita PPP i 2000 med indeks USA $=100$, mens andenaksen viser den gennemsnitlige årlige forskel i væksten i BNP per capita PPP mellem transitionslandene og USA over perioden 2000-2018.

Mens sigma-konvergens indikerer at landenes indkomstniveau nærmer sig hinanden, siger det ikke noget om retningen. Sigma-konvergens kan således være et udtryk for konvergens mod et lavt indkomstniveau. Det kan derfor også være nyttigt at undersøge om indkomsten nærmer sig niveauet i et velstående referenceland, altså om væksten i BNP per capita er hurtigere i lande som i udgangspunktet har et lavt BNP per capita end i lande med et højt BNP per capita. Er dette tilfældet, er der tale om beta-konvergens ( $\beta$-konvergens). Beta-konvergens betyder i princippet at underudvikling $\mathrm{i}$ et land kan betragtes som et forbigående fænomen.

Figur 5 viser et krydsplot med BNP per capita i år 2000 på førsteaksen og den gennemsnitlige årlige forskel i væksten i BNP per capita mellem transitionslandene og USA over perioden 2000-2018 på andenaksen. ${ }^{8}$ En negativ sammenhæng indikerer beta-konvergens, idet de lande som i udgangspunktet var fattige da ville have den højeste vækst, mens de bedre stillede lande ville have den laveste vækst.

Figur 5 indikerer at der ikke er en negativ sammenhæng mellem initialt produktionsniveau og efterfølgende vækst. Der er derimod en svagt positiv sammenhæng. Nogle af de aller fattigste transitionslande i 2000 havde over de næste to årtier økonomisk vækst som kun var marginalt højere end den amerikanske, mens nogle af de

${ }^{8}$ En værdi på 0,0 på andenaksen indikerer følgelig at et land har haft præcis same vækst som USA over perioden 2000-2018. 
bedst stillede lande i 2000 havde betydeligt højere vækst end den amerikanske. I den samlede gruppe af transitionslande er der ikke tegn på beta-konvergens.

Det er muligt at teste for beta-konvergens ved hjælp af økonometriske metoder. Den mest almindelige metode tager udgangspunkt i figur 5 og undersøger om indkomstvæksten over en periode kan "forklares" med indkomstniveauet i udgangsåret. Lidt notation er nyttigt. Det relative indkomstniveau i transitionsland $i$ betegnes som $Y_{i, 0}$ i udgangsåret 0 og som $Y_{i, T}$ i slutåret $T$, idet det relative indkomstniveau i begge tilfælde er BNP per capita PPP relativt til USA. Det er muligt at estimere følgende relation med tværsnitsdata: ${ }^{9}$

$$
\left(Y_{i, T}-Y_{i, 0}\right) / T=\alpha+\beta Y_{i, 0}+\varepsilon_{i}
$$

På venstre side er den gennemsnitlige årlige vækstforskel mellem transitionslandene og USA. Koefficienten $\beta$ angiver effekten af det oprindelige indkomstniveau, så $\beta<0$ indikerer beta-konvergens. Konstanten $\alpha$ opsamler vækstforskelle som ikke varierer mellem landene, mens restleddet $\varepsilon_{\mathrm{i}}$ angiver landespecifikke afvigelser. Relationen estimeres med mindste kvadraters metode (OLS), hvilket betyder at koeffici-

Tabel 2. Estimation af beta-konvergens for alle transitionslande, forskellige tidintervaller.

\begin{tabular}{lccccc}
\hline & $\mathbf{2 0 0 0 - 2 0 1 8}$ & $\mathbf{1 9 9 5 - 2 0 1 8}$ & $\mathbf{1 9 9 5 - 2 0 0 0}$ & $\mathbf{2 0 0 0 - 2 0 0 8}$ & $\mathbf{2 0 0 8 - 2 0 1 8}$ \\
\hline $\boldsymbol{\alpha}$ & $0,496^{\star \star \star}$ & $\begin{array}{c}0,464^{\star \star \star} \\
(0,133)\end{array}$ & $\begin{array}{c}0,055 \\
(0,170)\end{array}$ & $\begin{array}{c}0,607^{\star \star \star} \\
(0,215)\end{array}$ & $\begin{array}{c}0,366^{\star \star} \\
(0,143)\end{array}$ \\
\hline $\boldsymbol{\beta}$ & $0,011^{\star}$ & 0,007 & 0,001 & $0,029^{\star \star \star}$ & $-0,001$ \\
& $(0,006)$ & $(0,005)$ & $(0,007)$ & $(0,009)$ & $(0,004)$ \\
\hline $\mathbf{R}^{2}$ & 0,131 & 0,070 & 0,000 & 0,269 & 0,002 \\
\hline Obs. & 30 & 26 & 26 & 30 & 30 \\
\hline
\end{tabular}

Note: Standardfejl er angivet i parentes under koefficientestimaterne. Toptegn ${ }^{\star \star \star},{ }^{\star \star}$ og ${ }^{\star}$ angiver at koefficienten er statistisk signifikant på henholdsvis 1,5 og 10 procent-niveauet.

enterne bestemmes så der opnås den bedst mulige tilpasning mellem den estimerede relation og de tilgængelige observationer. Tabel 2 viser estimationsresultaterne for forskellige tidsintervaller. Alle transitionslande indgår i estimationerne, men antallet af lande for hvilke der er data afhænger af tidsintervallet.

Hovedresultatet findes i kolonnen for perioden 2000-2018, hvor der er data for alle 30 transitionslande. Den estimerede $\beta$-koefficient er $0,011 \mathrm{og}$ statistisk signifikant på 10 procent-niveauet. (De estimerede koefficienter er brugt som grundlag for regressionslinjen i figur 5.) Den positive $\beta$-koefficient indikerer, at der over perioden 2000-2018 har været beta-divergens, således at indkomstgabet over for USA

\footnotetext{
${ }^{9}$ Dette er en lineær version af den logaritmiske model, som ofte bruges til estimation af beta-konvergens (Varblane \& Vahter, 2006; Rapacki \& Prochniak, 2009; Ferrer, Di Salvo, Musmeci \& Pilati, 2018). Den lineære version er valgt fordi den er lettere at fortolke. I dette tilfælde med en kort tidhorisont og relativt små vækstforskelle giver den lineære og den logaritmiske model stort set de samme resultater.
} 
er indsnævret mest i de lande som i udgangspunktet var bedst stillet og mindst i de lande som havde et ugunstigt økonomisk udgangspunkt. For den længere periode 1995-2018 indgår kun 26 lande i estimationerne. Den estimerede $\beta$-koefficient er også her positiv og af stort set samme størrelse som for perioden 2000-2018, men den er dog ikke statistisk signifikant.

Betragtes de tre delperioder separat fremgår det at der i transitionsperioden fra 1995-2000 og i perioden fra 2008-2018 hverken har været tegn på divergens eller konvergens. Den overordnede tendens mod divergens kommer således fra boom-perioden 2000-2008. I denne periode er der en klar tendens til divergens idet den estimerede $\beta$-koefficient er positiv, forholdsvis stor og statistisk signifikant på 1 procent-niveauet. Den overordnede tendens til indkomstdivergens i transitionslandene stammer altså hovedsagelig fra boom-perioden før finanskrisen hvor de bedst stillede lande indsnævrede indkomstgabet over for USA langt hurtigere end tilfældet var for de fattigste lande.

Resultaterne i tabel 2 er robuste over for forskellige ændringer i specifikationerne. En bekymring kunne være om et lands konjunktursituation i udgangsåret kunne påvirke resultaterne i betydelig grad. Dette er imidlertid ikke tilfældet hvilket er relateret til at indkomstniveauet typisk ændrer sig relativt langsomt. ${ }^{10}$ En anden bekymring kunne være at enkeltlande med ekstreme observationer kunne spille en stor rolle, men eliminering af disse påvirker typisk kun resultaterne marginalt. ${ }^{11}$

Estimationerne indikerer at der ikke er beta-konvergens i den samlede gruppe af transitionslande. Transitionslandene er imidlertid på mange måder en heterogen samling af lande med meget forskellige økonomiske udfordringer og politiske valg (Rapacki \& Prochniak, 2009). Dette gør det relevant at teste for gruppe-konvergens, altså hvorvidt der er beta-konvergens inden for undergrupper af landene. Tabel 3

Tabel 3. Estimation af beta-konvergens over perioden 2000-2018, forskellige landegrupper

\begin{tabular}{lcccc}
\hline & Alle & CEE11 & Balkan6 & xSovjet13 \\
\hline $\boldsymbol{\alpha}$ & $0,496^{\star \star \star}$ & $1,756^{\star \star \star}$ & 0,487 & $0,334^{\star}$ \\
& $(0,133)$ & $(0,350)$ & $(0,274)$ & $(0,175)$ \\
\hline $\boldsymbol{\beta}$ & $0,011^{\star}$ & $-0,024^{\star \star}$ & $-0,003$ & $0,027^{\star}$ \\
\hline $\mathbf{R}^{2}$ & $(0,006)$ & $(0,010)$ & $(0,016)$ & $(0,013)$ \\
\hline Obs. & 0,131 & 0,374 & 0,010 & 0,283 \\
\hline
\end{tabular}

Note: Standardfejl er angivet i parentes under koefficientestimaterne. Toptegn $\star \star \star, \star \star$ og ${ }^{\star}$ angiver at koefficienten er statistisk signifikant på henholdsvis 1,5 og 10 procent-niveauet.

\footnotetext{
${ }^{10}$ Resultaterne $\mathrm{i}$ analyserne af beta-konvergens over perioden 2000-2018 er ikke afhængige af konjunktursituationen i udgangsåret. Resultaterne er således stort set uændrede når det initiale indkomstniveau for 2000 erstattes af gennemsnittet over årene 1998-2000.

${ }^{11}$ Estimation med mindste absolutte metode og vejede mindste kvadraters metode viser tilsvarende at ekstreme observationer ikke er af afgørende betydning for resultaterne.
} 
viser resultaterne af estimationer for perioden 2000-2018 for alle landene og for de tre undergrupper defineret tidligere. Billedet varierer betydeligt for de forskellige undergrupper hvilket også fremgår af figur 5 hvis landenes markører betragtes separat for hvert af de tre undergrupper.

Der er klar indikation på beta-konvergens i gruppen CEE11, idet den estimerede $\beta$-koefficient er negativ og statistisk signifikant på 5 procent-niveauet. Koefficientestimatet på -0,024 indikerer at disse lande hvert år gennemsnitligt har indsnævret indkomstgabet over for USA med ca. 2,4 procent. En tommelfingerregel siger at fattige lande typisk lukker indkomstgabet over for de udviklede lande med ca. 2 procent om året, omend den empiriske evidens for reglen måske ikke er overvældende (Sala-i-Martin, 1996; Abreu et al., 2005). Det er ikke desto mindre bemærkelsesværdigt at den fundne beta-konvergens for CEE11 gruppen er i tråd med denne tommelfingerregel.

For Balkan6 er resultaterne uklare, hvilket til dels skyldes det meget lille antal observationer. Beta-koefficienten er negativ, men numerisk meget lille og estimeret meget upræcist. For xSovjet13 gruppen er der tydelige tegn på beta-divergens. Den estimerede $\beta$-koefficient er positiv og statistisk signifikant på 10 procent-niveauet. I perioden fra 2000 til 2018 voksede indkomsterne i de rigeste lande i denne gruppe generelt hurtigere end de gjorde i de fattigste lande. Denne beta-divergens reflekterer alvorlige vækstproblemer i mange af de fattigste lande som udgik fra Sovjetunionen, herunder flere af landene i Centralasien, men også mere vestligt beliggende lande som Ukraine og Moldova.

Samlet set viser resultaterne at mens der ikke har været beta-konvergens for de 30 transitionslande samlet set over perioden 2000-2018 er billedet meget forskelligt mellem de tre grupper. Der har været gruppe-konvergens i CEE11 gruppen, gruppe-divergens i xSovjet13 gruppen og ingen af delene i Balkan6 gruppen. Dette mønster er endnu en afspejling af den meget store heterogenitet inden for de post-kommunistiske transitionslande.

\section{Afrunding}

Artiklen giver en oversigt over transitionslandenes økonomiske udvikling siden begyndelsen af reformprocessen i begyndelsen af 1990'erne. Alle landene havde fra starten planøkonomiske systemer, men samtidig er det vigtigt at holde sig for øje at deres økonomiske og institutionelle udgangspunkter var meget forskellige. Det samme gælder for omfanget og hastigheden af reformer, hvilket reflekterede forskellige politiske og økonomiske valg i landene.

Transitionslandene oplevede store produktionsfald i den tidlige transitionsfase. Siden har væksten været meget ustabil i de fleste lande som følge af blandt andet finansielle kriser, økonomiske blokader, interne uroligheder og krige. Transitionslandene har generelt oplevet kraftige konjunkturudsving på linje med dem der ofte ses i udviklings- og mellemindkomstlande som ikke har været igennem en postkommunistisk transition. 
Produktionen er over tid øget betydeligt i de fleste transitionslande, og landene har som gennemsnit betragtet indsnævret indkomstgabet til de mest udviklede lande. Der er imidlertid tegn på divergens idet de lande som i udgangspunktet var fattigst har haft langsommere indhentning af indkomstgabet end de lande som i udgangspunktet var bedre stillede. Den langsomme eller fraværende indhenting gælder specielt for flere af landene fra den tidligere Sovjetunion, mens der er klare tegn på konvergens inden for de 11 lande som i perioden er blevet medlemmer af EU.

Det økonomiske udbytte af transitionsprocessen er således ulige fordelt mellem landene. Flere lande i Central- og Østeuropa nærmer sig indkomstniveauet i mange vesteuropæiske lande, mens landene på Balkan er blevet sat tilbage af krige og politiske konflikter. Billedet er blandet for de lande, som udgik fra Sovjetunionen. Hviderusland og olieeksporterende lande som Rusland og Kasakhstan har været i stand til at indsnævre indkomstgabet. Flere lande i blandt andet Centralasien havde imidlertid store produktionsfald i 1990'erne og derefter en svag økonomisk udvikling. Næsten tre årtier efter Sovjetunionens sammenbrud er de blandt verdens fattigste udviklingslande.

Konklusionen er at der i økonomisk henseende har været stor og stigende heterogenitet inden for de post-kommunistiske transitionslande. 30 år efter Berlinmurens fald nærmer flere af landene sig vesteuropæiske produktionsniveauer, mens andre er blandt verdens fattigste udviklingslande. Den store heterogenitet inden for gruppen og de ulige gevinster fra transitionen betyder at de økonomiske udfordringer varierer stærkt mellem landene. I økonomisk sammenhæng giver det mindre og mindre mening at behandle og analysere transitionslandene under ét.

\section{Om artikkelen}

Tak til Rune Holmgaard Andersen og to anonyme fagfællebedømmere for nyttige kommentarer til tidligere versioner. Synspunkterne i artiklen er forfatterens egne og deles ikke nødvendigvis af Eesti Pank eller andre dele af Eurosystemet.

\section{Litteratur}

Abreu, M., de Groot, H. \& Florax, R. (2005). A meta-analysis of $\beta$-convergence: The legendary $2 \%$. Fournal of Economic Surveys, 19(3), 389-420.

Alcidi, C, Ferrer, J. N., Di Salvo, M., Musmeci, R. \& Pilati, M. (2018). Income convergence in the EU: A tale of two speeds. CEPS commentary, Centre for European Policy Studies, Hentet 4. juli 2019 fra https:// www.ceps.eu/system/files/ConvergencePDF.pdf.

Babecký, J., \& Campos, N. (2011). Does reform work? An econometric survey of the reform-growth puzzle. Fournal of Comparative Economics 39(2), 140-158.

Barro, R. \& Sala-i-Martin, X. (2004). Economic growth (2. udg.). Cambridge, M.A.: MIT Press.

Berglof, E., Foray, D., Landesmann, M., Lin, J.Y., Campos, M. N., Sanfey, P., Radosevic, S. \& Volchkova, N. (2015). Transition economics meets new structural economics. Fournal of Economic Policy Reform 18(3), 191-220.

Blanchard, O., Dornbusch, R., Krugman, P., Layard, R. \& Summers, L. (1991). Reform in Eastern Europe. Cambridge, M.A.: MIT Press. 


\section{8 | KARSTEN STÆHR}

Coricelli, F. \& Campos, N. (2002). Growth in transition: What we know, what we don't, and what we should. fournal of Economic Literature 40(3), 793-836.

Dabrowski, M., Gomulka, S. \& Rostowski, J. (2001). Whence reform? A critique of the Stiglitz perspective. fournal of Policy Reform 4(4), 291-324.

De Melo, M., Denizer, C., Gelb, A. \& Tenev, S. (2001). Circumstance and choice: The role of initial conditions and policies in transition economies. World Bank Economic Review 15(1), 1-31.

EBRD (2010). Macro economic indicators, Forecasts, macro data, transition indicators. Hentet 3. januar 2011 (link nedlagt), European Bank for Re-construction and Development.

EBRD (2017). Transition report 2017-18. London, UK: European Bank for Reconstruction and Development.

Estrin, S., Urga, G. \& Lazarova, S. (2001). Testing for ongoing convergence in transition economies, 1970 to 1998. Fournal of Comparative Economics 29(4), 677-691.

Falcetti, E., Lysenko, T. \& Sanfey, P. (2006). Reforms and growth in transition: Re-examining the evidence, Fournal of Comparative Economics, 34(3), 421-445.

Fidrmuc, J. (2003). Economic reform, democracy and growth during post-communist transition. European Fournal of Political Economics 19(3), 583-604.

Hellman, J. S. (1998). Winners take all: The politics of partial reform in postcommunist transitions. World Politics 50(2), 203-234.

Iwasaki, I. \& Kumo, K. (2016). Decline and growth in transition economies: A meta-analysis. Kyoto University Institute of Economic Research, KIER Working Papers 951.

Jones, C. I. (2016). The facts of economic growth. I J. B. Taylor \& H. Uhlig (red.), Handbook of macroeconomics 2 (s. 3-69), Amsterdam, NL: Elsevier.

Kornai, J. (2006). The great transformation of Central Eastern Europe. Success and disappointment. Economics of Transition 14(2), 207-244.

Levenko, N., Oja, K. \& Staehr, K. (2019). TFP growth in central and eastern Europe before, during and after the global financial crisis. Post-Communist Economies, 31(2), 137-160.

Mcgillivray, M. (1991). The human development index: yet another redundant composite development indicator? World Development 19(10), 1461-1468.

Rapacki, R. \& Prochniak, M. (2009). Real beta and sigma convergence in 27 transition countries, 1990-2005. Post-Communist Economies 21(3), 307-326.

Roland, G. (1994). On the speed and sequencing of privatisation and restructuring. Economic fournal 104(426), $1158-1168$.

Sala-i-Martin, X. (1996). Regional cohesion: Evidence and theories of regional growth and convergence. European Economic Review 40(6), 1325-1352.

Schneider, F., Buehn, A. \& Montenegro, C. (2010). New estimates for the shadow economies all over the world. International Economic fournal 24(4), 443-461.

Staehr, K. (2005). Reforms and economic growth in transition economies: Complementarity, sequencing and speed. European fournal of Comparative Economics 2(2), 177-202.

Staehr, K. (2006). Linkages between political and economic reforms in the post-communist countries. Nordic fournal of Political Economy 32(2), 113-138.

Staehr, K. (2015). Economic growth and convergence in the Baltic states: Caught in a middle income trap? Intereconomics 50(5), 274-280.

Staehr, K. (2018). Capital flows and growth dynamics in Central and Eastern Europe. Post-Communist Economies 30(1), 1-18.

Stiglitz, J. (2000). Whither reform? Ten years of the transition. I B. Pleskovic \& J. Stiglitz (red.), Proceedings of the annual bank conference on development economics 1999 (s. 27-56). Washington, D.C.: World Bank.

Varblane, U. \& Vahter, P. (2006). An analysis of the convergence process in the transition countries. I H. Hannula, S. Radoševic \& N. von Tunzelmann (red.): Estonia, the new EU economy. Building a Baltic miracle? (s. 19-46). Farnham, UK: Ashgate Publishing.

WEO (2019). World Economic Outlook database April 2019. Hentet 4. juli 2019 fra https://www.imf.org/ external/pubs/ft/weo/2018/01/weodata/index.aspx. 